\title{
OPTICAL PROPERTIES OF NOVEL RESIN MATRIX CERAMIC SYSTEMS AT DIFFERENT THICKNESSES
}

\begin{abstract}
Objectives: The purpose of this study was to investigate the effect of material and thickness on the translucency parameters (TP) and opalescence parameters (OP) for resin matrix ceramic blocks.
\end{abstract}

Materials and Methods: 90 disc-shaped specimens ( $8 \mathrm{~mm}$ diameter and A2 shade, High Translucency) were fabricated from Vita Enamic, Lava Ultimate and GC Cerasmart resin-matrix ceramic blocks and prepared to thicknesses of $0.5 \mathrm{~mm}, 1 \mathrm{~mm}$ and $1.5 \mathrm{~mm}(\mathrm{n}=10)$. A dental spectrophotometer (VITA Easyshade Advance) was used to calculate the TP and OP. All specimens were placed on white and black backgrounds. The color measurements were repeated three times for each of the specimens and the mean values of $\mathrm{L}$, a and $\mathrm{b}$ were calculated. Data were analyzed by a two-way analysis of variance (ANOVA) and Tukey's test.

Results: For the $0.5 \mathrm{~mm}$ thickness groups, GC Cerasmart had the highest and Vita Enamic had the lowest TP values. For the $1 \mathrm{~mm}$ thickness groups, GC Cerasmart had the highest TP, whereas Vita Enamic had the lowest TP. For the $1.5 \mathrm{~mm}$ thickness groups, Lava Ultimate had the highest TP, whereas Vita Enamic had the lowest TP. For the $0.5 \mathrm{~mm}$ thickness groups, Vita Enamic, and GC Cerasmart had the highest and lowest OP, respectively. The OP values in the $1 \mathrm{~mm}$ thickness group of Vita Enamic groups were higher than the GC Cerasmart and Lava Ultimate groups. The OP values in the $1.5 \mathrm{~mm}$ thickness group Lava Ultimate group were higher than the GC Cerasmart and Vita Enamic groups. In all groups, the OP values showed an increase in parallel with the increase in thicknesses, in contrast, the TP values showed a decrease.

Conclusions: Type and thickness of the resin matrix ceramics affect the optical properties of the materials.
ORCID IDs of the authors: E.Ç. 0000-0002-3797-770X B.G. $0000-0003-2430-866 \mathrm{X}$

\section{Keywords: Ceramics, color, spectrophotometry.}

\footnotetext{
How to Cite: Çelik E, Göktepe B. Optical Properties of Novel Resin Matrix Ceramic Systems at Different Thicknesses. Cumhuriyet Dent J 2019;22:2:176-184. *Corresponding Author:

Department of Prosthodontics, Faculty of Dentistry, Ordu University, Bülent Ecevit Street, Altınordu/Ordu/Turkey

Tel: +90 $5057486181 \quad$ Fax: +90 4522121289 E-mail: ersancelik@gmail.com
} 


\section{INTRODUCTION}

The goal of restorative and prosthetic dentistry is to restore the lost tooth structure using aesthetic materials that mimic the physical and structural properties of natural teeth. ${ }^{1}$ While ceramic and composite materials have been used in restorations for many years, both materials have several disadvantages. In order to eliminate these disadvantages, more studies have investigated the production of materials with improved properties. $^{2-4}$

While ceramics have advantages, such as high bending strength, biocompatibility, and color stability, they also have disadvantages, such as abrasion of the antagonist teeth and the consequent loss of tooth structure. These negative properties of ceramics are better for resins, but the material wear is higher. ${ }^{5}$ Nowadays, new materials known as resin matrix ceramics (RMC) have been developed that combine the positive properties of ceramics and composites. ${ }^{4}$

Novel ceramic reinforced polymers, a combination of the ceramic and polymer phases, have been developed with innovative processes. ${ }^{6}$ For this purpose, a new polymer infiltrated ceramic network (PICN) material has been developed that mimics the structure of natural teeth and improves their physical properties. ${ }^{1}$ This material (Vita Enamic, Vita Zahnfabrik, Bad Sackingen, Germany) consists of a double network system comprised of a feldspathic ceramic network ( $86 \%$ by weight $/ 75 \%$ by volume) and a polymer network ( $14 \%$ by volume $/ 25 \%$ by weight). ${ }^{7}$ Another resin matrix ceramic, Lava Ultimate, which is a resin nanoceramic, consists of nano-ceramic particles in the resin matrix of $80 \%$ by weight. High nanoceramics consist of a combination of discrete silica nanoparticles (20 $\mathrm{nm}$ in diameter), zirconia nanoparticles (4 $\mathrm{nm}$ to $11 \mathrm{~nm}$ in diameter), and zirconia-silica nanoclusters. ${ }^{4}$ GC Cerasmart, one type of nanoceramic RCM, is a high-intensity material containing $71 \%$ filler particles by weight. ${ }^{8}$ Lava Ultimate, Vita Enamic, and GC Cerasmart materials have indications for use in inlay, onlay, and veneer restorations. ${ }^{9}$
The appearance of materials is evaluated by the amount of light that they transmit or reflect. The translucency of the material is one of the most important factors in providing aesthetics, and it is an important factor in the choice of the material used in the restoration. ${ }^{10}$ Translucency is the state between transparency and opacity that allows for the transition of light through the material. ${ }^{11}$ Increased light transmission through the material demonstrates that the material is more translucent. ${ }^{12}$ In dentistry, the translucency of the materials is usually determined by the translucency parameter (TP), which is the measurement of color differences on the black and white background of the sample. A high TP value indicates that the materials have high translucency. ${ }^{13}$

Another important optical characteristic of ceramic materials is opalescence, which refers to the scattering of shorter wavelengths of visible light. This feature provides a bluish appearance when the color is reflected, and an orange/brown appearance when the color is transmitted. ${ }^{14}$

RMC blocks are novel materials; thus, very few previous studies have investigated their translucency. This study aimed is to examine the translucency and opalescence values of different RMC materials at different thicknesses. The first null hypothesis of this study is that there is no difference between the translucencies of different RMC materials at different thicknesses. The second null hypothesis is that there is no difference between the opalescence properties of different RMC materials at different thicknesses.

\section{MATERIALS AND METHODS}

\section{Preparation of the specimens}

The three different RCM blocks $(12 \times 14 \times 18 \mathrm{~mm})$, Vita Enamic (Vita Zahnfabrik, Bad Säckingen, Germany), Lava Ultimate (3M ESPE, St. Paul, MN, USA), and GC Cerasmart (GC Dental Products Corp., Aichi, Japan), used in the present study are shown in Table 1 . The A2 color and high translucency (HT) of these blocks were investigated. 
Table 1. Material, material type, composition, manufacturer and shade of all tested materials in the study

\begin{tabular}{|c|c|c|c|c|}
\hline Material & Material type & Composition & Manufacturer & Shade \\
\hline Vita Enamic & $\begin{array}{l}\text { Polimer } \\
\text { infiltrated } \\
\text { resin ceramic }\end{array}$ & $\begin{array}{l}\text { Polymer-infiltrated-feldspathic-ceramic-network } \\
\text { material (UDMA, TEGDMA) with } 86 \text { wt } \% \text { ceramic } \\
\left(\mathrm{SiO}_{2}, \mathrm{Al}_{2} \mathrm{O}_{3}, \mathrm{Na}_{2} \mathrm{O}, \mathrm{K}_{2} \mathrm{O} \text {, and other oxides }\right)\end{array}$ & $\begin{array}{l}\text { Vita Zahnfabrik, Bad } \\
\text { Säckingen, Germany }\end{array}$ & HT 2M2 \\
\hline GC Cerasmart & Nanoceramic & $\begin{array}{l}\text { Composite resin material (Bis-MEPP, UDMA, } \\
\text { DMA) with } 71 \text { wt\% silica and barium glass } \\
\text { nanoparticles }\end{array}$ & $\begin{array}{l}\text { GC Dental Products } \\
\text { Corp., Aichi, Japan }\end{array}$ & HT 2M2 \\
\hline Lava Ultimate & Resin nanoceramic & $\begin{array}{l}\text { Composite resin material (Bis-GMA, UDMA, Bis- } \\
\text { EMA, TEGDMA) with } 80 \mathrm{wt} \% \text { silica and barium } \\
\text { glass nanoparticles and zirconia/silica nanoclusters }\end{array}$ & $\begin{array}{l}\text { 3M ESPE, St.Paul, MN, } \\
\text { USA }\end{array}$ & HT $2 \mathrm{M} 2$ \\
\hline
\end{tabular}

First, the RMC blocks were milled in the computer-aided manufacturing (CAM) unit (Yenamak D50, Yenadent Ltd, Istanbul, Turkey) and $8 \mathrm{~mm}$ diameter cylinder blocks were obtained. The RMC blocks were cut into circular slices of $0.5 \mathrm{~mm}, 1 \mathrm{~mm}$, and $1.5 \mathrm{~mm}$ thickness using a diamond saw (Diamond cut-off wheels type LM+ Ø $100 \mathrm{~mm}$, Presi SA, Angonnes, France) and a precision cutting machine (Mecatom T180; Presi SA, Angonnes, France) at a speed of $290 \mathrm{rpm}$ under constant water cooling. All the specimens were polished using 600, 800, and 1200 grit silicon carbide paper (Atlas Zimpara, İstanbul, Turkey). Then, the prepared specimens were ultrasonically cleaned for 10 minutes in the ultrasonic cleaner (Skymen Heatable Ultrasonic Cleaner JP-4820, Shenzhen, China). In all, 90 circular samples $(8 \mathrm{~mm}$ diameter) with three different thicknesses $(0.5 \mathrm{~mm}, 1.0 \mathrm{~mm}$, and 1.5 $\mathrm{mm}$ ) were prepared for each of the RMC blocks $(n=10)$. All the specimens were carefully evaluated using a digital micrometer (Mitutoyo Corporation, Kanagawa, Japan) to ensure that the $0.5 \mathrm{~mm}, 1 \mathrm{~mm}$, and $1.5 \mathrm{~mm}$ thicknesses of each sample were even.

\section{Evaluation of the translucency and opalescence parameters}

The color values of all the samples were registered based on the Commission Internationale de l'Elcairage (CIE) $\mathrm{L}^{*} \mathrm{a}^{*} \mathrm{~b}^{*}$ system. In this system, the $\mathrm{L}$ value is the lightness-darkness axis, the a value is the redgreen axis, and the b value is the yellow-blue axis $^{15}$. In present study, the translucency and opalescence values on a black background $(\mathrm{L}=$ 1.06, $\mathrm{a}=-1.3, \mathrm{~b}=0.8$ ) and a white background $(\mathrm{L}=96.2, \mathrm{a}=-0.7, \mathrm{~b}=1.8)$ were measured relative to the D65 standard illuminant using a digital spectrophotometer (VITA Easyshade Advance, Bad Sackingen, Germany).

Before each measurement, the digital spectrophotometer was calibrated based on the manufacturer's instructions. To ensure standardization, all measurements were made from the center of the samples. Each sample was measured three times, and the mean value was recorded.

In the present study, TP was determined using the following formula ${ }^{16}$ : $\mathrm{TP}=\sqrt{\left(L_{B}-L_{W}\right)^{2}+\left(a_{B}-a_{W}\right)^{2}+\left(b_{B}-b_{W}\right)^{2}}$

To calculate the opalescence parameter (OP), the $\mathrm{a}$ and $\mathrm{b}$ parameter values on the black background and white background were used, as shown in the following formula ${ }^{16}$ :

$\mathrm{OP}=\sqrt{\left(a_{B}-a_{W}\right)^{2}+\left(b_{B}-b_{W}\right)^{2}}$

Materials with a high OP have a higher opalescence. ${ }^{17}$

The color parameters in the black background were indicated with a subscript $\mathrm{B}$, and the subscript $\mathrm{W}$ was used for the color parameters in the white background. ${ }^{13}$

\section{Statistical analysis}

All of the statistical analyses were conducting using SPSS software (SPSS Inc., Chicago, IL USA). Levene's test was used to evaluate the homogeneity of the variances. Data from the optical properties were statistically compared using two-way analysis of variance (ANOVA) and the Tukey's Honest Significant Difference (HSD) post-hoc test. The analysis was performed with a confidence level of 0.05 .

\section{RESULTS}

TP values varied from 28.93 to 32.67 in the $0.5 \mathrm{~mm}$ thickness group. GC Cerasmart specimens showed higher TP values than Lava Ultimate specimens, while Lava Ultimate specimens showed higher TP 
values than Vita Enamic specimens (Table 2). Significant differences were observed between all groups in $0.5 \mathrm{~mm}$ thickness $(\mathrm{p}<0.05)$.

In the $1.0 \mathrm{~mm}$ thickness group, TP values varied between 20.14 to 24.40. GC Cerasmart had the highest TP, whereas Vita Enamic had the lowest TP. Although there was no significant difference between Lava Ultimate and GC Cerasmart ( $p>0.05$ ); Lava Ultimate and GC Cerasmart indicated significantly higher TP values than Vita Enamic $(\mathrm{p}<0.05)$.

For the $1.5 \mathrm{~mm}$ thickness groups, Lava Ultimate had the highest TP, whereas Vita Enamic had the lowest TP. Although a significant difference wasn't observed between Lava Ultimate and GC Cerasmart ( $>0.05)$; Lava Ultimate and GC Cerasmart indicated significantly higher translucency values than Vita Enamic $(\mathrm{p}<0.05)$.

When different thicknesses of the same material group were compared, a statistically significant difference was observed between 0.5 $\mathrm{mm}, 1 \mathrm{~mm}, 1.5 \mathrm{~mm}$ groups of all material groups $(\mathrm{p}<0.05)$.

The results of the mean translucency values of the different RMC blocks in different thickness are shown in Table 2 and Figure 1.

For the $0.5 \mathrm{~mm}$ thickness groups, Vita Enamic, and GC Cerasmart had the highest and lowest OP, respectively. Vita Enamic specimens showed higher OP values than Lava Ultimate specimens, while Lava Ultimate specimens showed higher OP values than GC Cerasmart specimens (Table 2). Between the all groups had significantly different values $(\mathrm{p}<0.05)$.

The OP values in the $1 \mathrm{~mm}$ thickness group of Vita Enamic groups were higher than the GC Cerasmart and Lava Ultimate groups. Although there was no significant difference between Lava Ultimate and Vita Enamic ( $>0.05)$; Lava Ultimate and Vita Enamic showed significantly higher opalescence values than GC Cerasmart $(\mathrm{p}<0.05)$.

The OP values in the $1.5 \mathrm{~mm}$ thickness group Lava Ultimate groups were higher than the GC Cerasmart and Vita Enamic groups. Although there was no significant difference between Vita Enamic and GC Cerasmart( $p>0.05)$; Lava Ultimate showed significantly higher opalescence values than GC Cerasmart and Vita Enamic ( $\mathrm{p}<0.05)$.

The results of the mean opalescence values of the different RMC blocks in different thickness are shown in Table 2 and Fig. 2.

In all groups, the OP values showed an increase in parallel with the increase in thicknesses, in contrast, the TP values showed a decrease.

Table 2. The mean translucency and opalescence values of the groups and their comparisons

\begin{tabular}{ccccccc}
\hline & & \multicolumn{3}{c}{ TP } & \multicolumn{3}{c}{ OP } \\
\hline Material & $\mathbf{0 . 5} \mathbf{~ m m}$ & $\mathbf{1 ~ m m}$ & $\mathbf{1 . 5} \mathbf{~ m m}$ & $\mathbf{0 . 5} \mathbf{~ m m}$ & $\mathbf{1 ~ m m}$ & $\mathbf{1 . 5} \mathbf{~ m m}$ \\
Lava Ultimate & $31.27( \pm 1.04)^{\mathrm{Aa}}$ & $23.73( \pm 0.73)^{\mathrm{Ab}}$ & $18.03( \pm 0.77)^{\mathrm{Ac}}$ & $4.93( \pm 0.25)^{\mathrm{Aa}}$ & $6.85( \pm 0.31)^{\mathrm{Ab}}$ & $8.35( \pm 0.27)^{\mathrm{Ac}}$ \\
VitaEnamic & $28.93( \pm 1.31)^{\mathrm{Ba}}$ & $20.14( \pm 0.48)^{\mathrm{Bb}}$ & $14.82( \pm 0.52)^{\mathrm{Bc}}$ & $5.59( \pm 0.31)^{\mathrm{Ba}}$ & $7.03( \pm 0.17)^{\mathrm{Ab}}$ & $6.78( \pm 0.18)^{\mathrm{Bb}}$ \\
GC Cerasmart & $32.67( \pm 0.90)^{\mathrm{Ca}}$ & $24.40( \pm 0.96)^{\mathrm{Ab}}$ & $17.87( \pm 0.98)^{\mathrm{Ac}}$ & $3( \pm 0.41)^{\mathrm{Ca}}$ & $5.46( \pm 0.23)^{\mathrm{Bb}}$ & $6.54( \pm 0.15)^{\mathrm{Bc}}$ \\
\hline
\end{tabular}

Superscripts with capital letters show the differences between material types and lower case letters show differences between thicknesses.

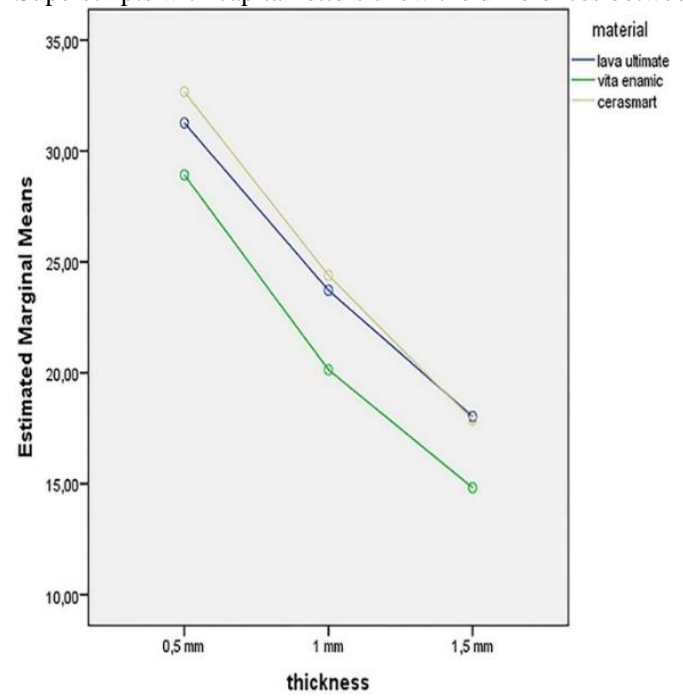

Figure 1. Translucency values of the groups

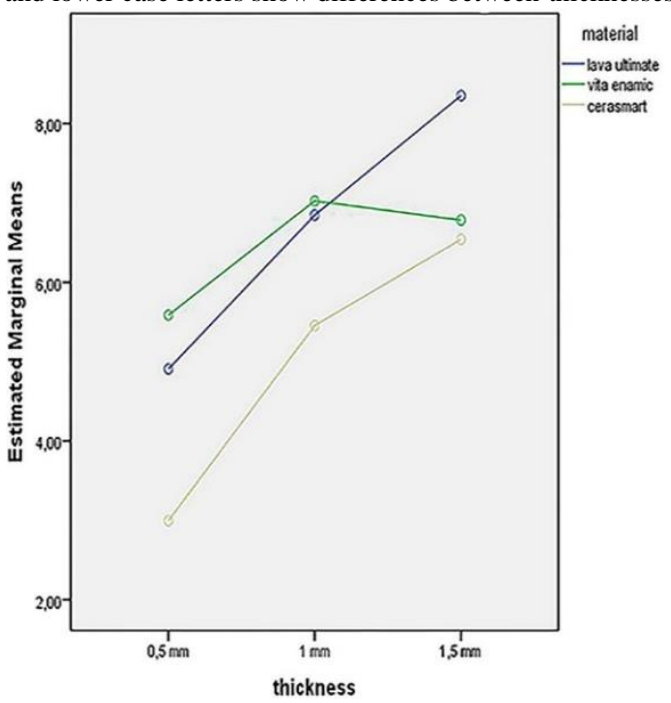

Figure 1. Translucency values of the groups 


\section{DISCUSSION}

Two null hypotheses were rejected because there were significant differences between the TP and OP values of the various thicknesses of the tested RMC blocks.

Novel hybrid dental materials, called RMC, combine the clinically useful properties of ceramics and composites. ${ }^{18}$ In the present study, the optical properties of Vita Enamic, GC Cerasmart, and Lava Ultimate RMC materials, which are indicated for laminate veneer restorations, were evaluated.

Vita Enamic, a polymer-infiltrated resin ceramic, contains an $86 \%$ ceramic matrix and a $14 \%$ polymer network. ${ }^{19}$ The flexural strength of Vita Enamic is $150-160 \mathrm{MPa}$, and the elastic modulus and stiffness (hardness) of this material are $30 \mathrm{GPa}$ and $2.5 \mathrm{GPa}$, respectively. ${ }^{20}$ The nanoceramic particles in the resin matrix constitute $80 \%$ of the weight of the Lava Ultimate material, a resin nano-ceramic. ${ }^{7}$ The flexural strength of Lava Ultimate is $200 \mathrm{MPa}$, and the elastic modulus has been reported as $29.8 \mathrm{GPa} .{ }^{21}$ For GC Cerasmart, a nano-ceramic, $71 \%$ of its weight is filler particles (silica and barium), and the resin matrix consists of BisMEPP, UDMA, and DMA. ${ }^{22}$ The flexural strength of GC Cerasmart is 238 $\mathrm{MPa},{ }^{23}$ and the elastic modulus is $12.1 \mathrm{GPa}^{24}$

Previous studies ${ }^{25-27}$ have evaluated the effect of thickness on the translucency of materials. Wang et al. ${ }^{25}$ researched the TP values of $2 \mathrm{~mm}$ thick specimens of glass ceramics and $1 \mathrm{~mm}$-thick specimens of zirconia ceramics, and they stated that the translucency of all materials increased as the thickness decreased. Barizon et al. ${ }^{26}$ examined the effect of thickness on the translucency of restorative materials and concluded that TP increased as thickness decreased. Vichi et al. ${ }^{27}$ investigated the translucency properties of Cerec CAD-CAM materials with thicknesses of 0.5 and $1.0 \mathrm{~mm}$ and found that there were decreases in translucency due to increases in thickness.

The total refractive index and thickness of a material are directly related to each other ${ }^{16}$. Since light transmission decreases due to increases in thickness, the TP value of a material decreases. In our study, as the thickness of the materials increased, the TP values decreased, and the OP values increased.

In the present study, the mean TP values in the $0.5 \mathrm{~mm}$ thickness group were evaluated as 28.93 for Vita Enamic, 31.27 for Lava Ultimate, and 32.67 for GC Cerasmart. The GC Cerasmart specimens showed higher TP values than the Lava Ultimate specimens while the Lava Ultimate specimens had higher TP values than the Vita Enamic specimens. There were significantly different values among all groups $(\mathrm{p}<0.05)$. The TP values in the $1 \mathrm{~mm}$ thickness group of Vita Enamic (20.14) were lower than the GC Cerasmart (24.40) and Lava Ultimate (23.73) groups. The TP values in the $1.5 \mathrm{~mm}$ thickness groups both of GC Cerasmart (17.87) and Lava Ultimate (18.03) were higher than in the Vita Enamic (14.82) group. Lava Ultimate and GC Cerasmart showed significantly higher translucency values than Vita Enamic $(\mathrm{p}<0.05)$ in the $1 \mathrm{~mm}$ and $1.5 \mathrm{~mm}$ thickness groups.

In the present study, for the $0.5 \mathrm{~mm}$ thickness groups, Vita Enamic (5.59) and GC Cerasmart (3) had the highest and lowest OP values, respectively, and there were significantly different values among all the groups $(\mathrm{p}<0.05)$. The OP values in the $1 \mathrm{~mm}$ thickness group of Vita Enamic (7.03) were higher than in the GC Cerasmart (5.46) and Lava Ultimate (6.85) groups. Although no significant difference was observed between Lava Ultimate and Vita Enamic ( $>>0.05$ ), Lava Ultimate and Vita Enamic showed significantly higher opalescence values than GC Cerasmart $(\mathrm{p}<0.05)$. The OP values in the $1.5 \mathrm{~mm}$ thickness group of Lava Ultimate (8.35) were higher than in the GC Cerasmart (6.54) and Vita Enamic (6.78) groups. Although no significant difference was observed between Vita Enamic and GC Cerasmart ( $p>0.05$ ), Lava Ultimate showed significantly higher opalescence values than GC Cerasmart and Vita Enamic ( $\mathrm{p}<0.05$ ).

Awad et al. ${ }^{11}$ examined the translucency values of the $1 \mathrm{~mm}$ and $2 \mathrm{~mm}$ thick Vita Enamic and Lava Ultimate materials and reported that Lava Ultimate showed higher translucency values than Vita Enamic. In this study, Lava Ultimate showed values of 42.10 and 24.96 in the $1 \mathrm{~mm}$ and $2 \mathrm{~mm}$ thickness groups (respectively) whereas 
Vita Enamic showed 23.92 and 11.28 values in the $1 \mathrm{~mm}$ and $2 \mathrm{~mm}$ thickness groups, respectively. In the study, it was reported that Vita Enamic showed a lower TP value due to the high content of $\mathrm{Al}_{2} \mathrm{O}_{3}$; additionally, the nano-filler particles in this material are smaller than the wavelength of visible light, which results in less light scatter and higher translucency. This also explains the high TP value of the Lava Ultimate material containing nano-filler particles.

In a similar study using 0.5 mm-thick samples, lower translucency values were obtained for Vita Enamic (24.95), GC Cerasmart (31.16), and Lava Ultimate (29.84). ${ }^{16}$ There were significantly different values among all the groups at $0.5 \mathrm{~mm}$ thickness $(\mathrm{p}<0.05)$. In the same study, lower translucency values were obtained compared to our study in the $1 \mathrm{~mm}$ samples of Vita Enamic (14.15), GC Cerasmart (18.64), and Lava Ultimate (17.93). Although no significant difference was observed between Lava Ultimate and GC Cerasmart ( $p>0.05$ ), Vita Enamic showed significantly lower translucency values than GC Cerasmart and Lava Ultimate in the $1 \mathrm{~mm}$ thickness group ( $\mathrm{p}<0.05)$.

Sarkaya et al. ${ }^{28}$ examined the TP values of 1 mm-thick Vita Enamic and Lava Ultimate samples. As a result of this research, the Vita Enamic group's TP value was 19.1 and the TP of the Lava Ultimate group was 19.2; no significant difference was observed between the Lava Ultimate and Vita Enamic groups. The reason for the differences in the statistical significance between these other studies and the current study may be related to the $\mathrm{L}^{*} \mathrm{a}^{*} \mathrm{~b}^{*}$ values of the background used in the translucency measurements.

Pecho et al. ${ }^{29}$ compared the TP values of 0.5 mm-thick human and bovine dentin and zirconia systems, and they reported that no statistically significant difference was observed between the dentin and zirconia groups. In a study by $\mathrm{Yu}$ et al. ${ }^{30}$ human dentin indicated lower TP values and higher CIE $L^{*} a^{*} b *$ values than human enamel of the same thickness, and the mean TP values of 1 mm-thick human enamel and human dentin were 18.7 and 16.4 , respectively.
Gunal et al. ${ }^{16}$ examined the TP and OP values of Vita Suprinity and other novel CAD / CAM materials. As a result of research, the TP values of Vita Suprinity with thicknesses of 0.5 $\mathrm{mm}$ and $1 \mathrm{~mm}$ were reported as 23.30 and 14.26 and OP values as 10.07 and 10.56, respectively. Vita Suprinity showed significantly lower TP values in the $0.5 \mathrm{~mm}$ thickness group compared to Lava Ultimate, Vita Enamic, and GC Cerasmart. While no significant difference was observed between Vita Suprinity and Vita Enamic in $1 \mathrm{~mm}$ thickness group; Vita Suprinity showed significantly lower TP values compared to GC Cerasmart and Lava Ultimate. Suprinity (VITA Zahnfabrik, Bad Sackingen, Germany), another block of the novel CAD / CAM blocks, is a zirconia-reinforced lithium silicate ceramic. ${ }^{31}$

Many factors such as the resin matrix and filler composition and this composition content, pigment, and other additives affect the optical properties of the resin materials. ${ }^{32}$ The filler content, shape and size of Vita Enamic, Lava Ultimate and GC Cerasmart materials used in the present study were different.

In most of the studies evaluating the optical properties of_materials, researchers were preferred the use of materials of A2 color. ${ }^{16,22}$ In order to compare the optical properties of restorative materials with other studies and to obtain standardization, was preferred to use of A2 color HT blocks for all groups in the present study.

The color of residual tooth structure or the substructure material ought to be take consider while deciding the correct prosthetic material. In this study, the material type and thickness significantly affected the optical properties of RMCs. Therefore, to obtain natural looking restorations and provide correct shade matching with neighboring dentition especially for anterior teeth, RMCs should be carefully chosen due to their different optical properties.

Three methods are used to evaluate the translucency of materials used in dentistry, and these methods can be classified as direct transmission, total transmission, and spectral reflection. ${ }^{33} \mathrm{TP}$ is described as the difference between the reflected colors of a material of equal thickness on the background in two different 
colors, black and white, and this study the TP value was evaluated by determining the spectral reflections. ${ }^{13}$ Generally, spectrophotometers have been preferred for instrumental translucency determination. ${ }^{34-37}$ The spectroradiometer (SR) was introduced as an alternative color measuring device to the spectrophotometer in dentistry. ${ }^{38}$ With the use of a spectroradiometer (SR), the effect of edge-loss can be avoided since there is no aperture between the spectroradiometer, the light source, and the material. ${ }^{39}$ Lim et $a l .{ }^{33}$ reported that the TP values obtained with spectrophotometer and spectroradiometer showed a high correlation.

In this study, the spectrophotometer was used for the measurement of $\mathrm{TP}$ values since it is simpler to use and is preferred in previous studies. There may be differences between the spectroradiometer and spectrophotometer measurements. The limitation of this study is that measurements are done with spectrophotometer only.

The color of the teeth to be restored is important in determining the color and translucency of the restorative materials. While teeth without discoloration can be restored with more translucent materials, more opaque materials are preferred for teeth with discoloration. In this study, the TP and OP values of resin matrix ceramic materials were determined and it was investigated which materials could be more advantageous in clinical use.

\section{CONCLUSIONS}

Choosing the right restorative material in the anterior region is a critical issue for achieving natural looking aesthetic restorations. According to the findings of this study GC Cerasmart has the highest TP value in $0.5 \mathrm{~mm}$ and $1 \mathrm{~mm}$ thickness groups. For the $1.5 \mathrm{~mm}$ thickness groups, Lava Ultimate and GC Cerasmart indicated significantly higher translucency values than Vita Enamic. GC Cerasmart has the lowest OP value for all thickness groups. As the thickness of materials increased, TP values decreased and OP values increased. The use of GC Cerasmart and Lava Ultimate materials may be appropriate in anterior aesthetic restorations, as the use of materials with a high TP value is advantageous.

\section{ACKNOWLEDGEMENTS}

None

\section{CONFLICT OF INTEREST}

None

\section{Güncel Rezin Matriks Seramiklerin Farklı Kalınlıklardaki Optik Özellikleri \\ $\ddot{O} Z$}

Amaç: Bu çalışmanın amacı, rezin matriks seramik blokların materyal çeşitlerinin ve kalınlıklarının translusensi parametrelerine (TP) ve opalesans parametrelerine $(O P)$ etkilerini araştırmaktır. Gereç ve Yöntemler: Vita Enamic, Lava Ultimate ve GC Cerasmart rezin matriks seramik bloklarından oluşan 90 adet disk şeklindeki örnek (8 mm çap ve A2 renk, yüksek translusensi) 0,5 mm, $1 \mathrm{~mm}$ and $1,5 \mathrm{~mm}$ kalınlıklarında hazırlandı. TP ve OP değerlerini ölçmek için dental spektrofotometre (VITA Easyshade Advance) kullanıld. Tüm örnekler beyaz ve siyah zemin üzerine yerleştirilip renk ölçümleri her örnek için 3 defa tekrarland ve $L$, $a$ ve $b$ değerleri hesaplandı. Istatistiksel analizler, çift yönlü varyans analizi (ANOVA) ve Tukey testleri ile yapıld. Bulgular: $0,5 \mathrm{~mm}$ kalınlığındaki gruplarda, GC Cerasmart en yüksek, Vita Enamic ise en düşük TP dĕ̆erleri göstermiştir.1 ve 1,5 $\mathrm{mm}$ kalınlı̆̆ındaki gruplarda, GC Cerasmart ve Lava Ultimate yüksek TP değerleri gösterirken, Vita Enamic düşük TP dĕ̆eri göstermiştir. OP değerleri ise $0,5 \mathrm{~mm}$ kalınlı̆̆ındaki gruplarda, Vita Enamic'te en yüksekken GC Cerasmart'ta en düşük bulunmuştur. $1 \mathrm{~mm}$ kalınlığındaki gruplarda Lava Ultimate ve Vita Enamic, GC Cerasmart'a göre daha yüksek OP değerleri göstermiştir. $1,5 \quad \mathrm{~mm}$ kalınlı̆̆ındaki gruplarda, Lava Ultimate, GC Cerasmart ve Vita Enamic gruplarına göre daha yüksek OP değerleri göstermiştir. Tüm gruplarda, OP değerleri kalınlı̆̆ın artmaslyla paralel bir artma gösterirken, tam tersine TP değerleri azalma göstermiştir. Sonuç: Rezin matriks seramiklerin çeşitleri ve kalınlıkları, materyallerin optik özelliklerini etkilemektedir. Anahtar Kelimeler: Seramikler, renk, spektrofotometri. 


\section{REFERENCES}

1. Coldea A, Swain MV, Thiel N. Mechanical properties of polymer-infiltrated-ceramic-network materials. Dent Mater 2013;29:419-426.

2. Hampe R, Lümkemann N, Eichberger M, Stawarczyk

B. Fracture toughness analysis of ceramic and resin composite CAD/CAM material. Oper Dent 2019 Mar 8.

3. Bajraktarova-Valjakova E, Korunoska-Stevkovska V, Kapusevska B, Gigovski N, Bajraktarova-Misevska C, Grozdanov A. Contemporary dental ceramic materials, A review: Chemical composition, physical and mechanical properties, indications for use. Open Access Maced J Med Sci 2018;24:1742-1755.

4. Çelik E, Sahin SC, Dede DÖ. Shear bond strength of nanohybrid composite to the resin matrix ceramics after different surface treatments. Photomed Laser Surg. 2018; 36:424-430.

5. Dirxen C, Blunck U, Preissner S. Clinical performance of a new biomimetic double network material. Open Dent J 2013;7:118-122.

6. Duarte S, Sartori N, Phark JH. Ceramic-reinforced polymers: CAD/CAM hybrid restorative materials. Curr Oral Health Rep 2016;3:198-202.

7. Gracis S, Thompson VP, Ferencz JL, Silva NR, Bonfante EA. A new classification system for allceramic and ceramic-like restorative materials. Int $\mathbf{J}$ Prosthodont 2015;28:227-235.

8. Awada A, Nathanson D. Mechanical properties of resin-ceramic CAD/CAM restorative materials. J Prosthet Dent 2015;114:587-593.

9. Shetty R, Shenoy K, Dandekeri S, Suhaim KS, Ragher M, Francis J. Resin-matrix ceramics: an overview. Int J Rec Sci Res 2015;6:7414-7417.

10. Kelly JR, Nishimura I, Campbell SD. Ceramics in dentistry: historical roots and current perspectives. J Prosthet Dent 1996;75:18-32.

11. Awad D, Stawarczyk B, Liebermann A, Ilie N. Translucency of esthetic dental restorative CAD/CAM materials and composite resins with respect to thickness and surface roughness. J Prosthet Dent 2015;113:534-540.

12. Nogueira AD, Della Bona A. The effect of a coupling medium on color and translucency of CADCAM ceramics. J Dent 2013;41:18-23.

13. Johnston WM, Ma T, Kienle BH. Translucency parameter of colorants for maxillofacial prostheses. Int J Prosthodont 1995;8:79-86.
14. Cho MS, Yu B, Lee YK. Opalescence of allceramic core and veneer materials. Dent Mater 2009;25:695-702.

15. G Fehmi, Ç Ersan, Ö Caner. Influence of repeated firings on the color parameters of two different allceramic materials. Color Res Appl 2018;43:606-611

16. Gunal B, Ulusoy MM. Optical properties of contemporary monolithic CAD-CAM restorative materials at different thicknesses. J Esthet Restor Dent 2018;30:434-441.

17. Lee YK, Lu H, Powers JM. Changes in opalescence and fluorescence properties of resin composites after accelerated aging. Dent Mater 2006;22:653-660.

18. Spitznagel FA, Horvath SD, Guess PC, Blatz MB. Resin bond to indirect composite and new ceramic/ polymer materials: a review of the literature. $J$ Esthet Restor Dent 2014;26:382-393.

19. Leung BT, Tsoi JK, Matinlinna JP, Pow EH. Comparison of mechanical properties of three machinable ceramics with an experimental fluorophlogopite glass ceramic. J Prosthet Dent 2015;114:440-446.

20. Vita Enamic Technical and Scientific Documentation, 2013.

21. Lauvahutanon S, Takahashi $H$, Shiozawa M, Iwasaki N, Asakawa Y, Oki M, Arksornnukit M. Mechanical properties of composite resin blocks for CAD/CAM. Dent Mater 2014;33:705-710.

22. Stawarczyk B, Liebermann A, Eichberger M, Güth JF. Evaluation of mechanical and optical behavior of current esthetic dental restorative CAD/CAM composites. J Mech Behav Biomed Mater 2016;55:111.

23. Cerasmart for PlanMill Brochure, 2016.

24. Lawson NC, Bansal R, Burgess JO. Wear, strength, modulus and hardness of $\mathrm{CAD} / \mathrm{CAM}$ restorative materials. Dent Mater 2016;32:275-283.

25. Wang F, Takahashi H, Iwasaki N. Translucency of dental ceramics with different thicknesses. J Prosthet Dent 2013;110:14-20.

26. Barizon KT, Bergeron C, Vargas MA, Qian F, Cobb DS, Gratton DG, Geraldeli S. Ceramic materials for porcelain veneers: part II. Effect of material, shade, and thickness on translucency. J Prosthet Dent 2014;112:864-870.

27. Vichi A, Carrabba M, Paravina R, Ferrari M. Translucency of ceramic materials for CEREC CAD/CAM system. J Esthet Restor Dent 2014;26:224231. 
28. Sarkkaya I, Güleç C. Evaluation Of Translucency And Color Stability Of Esthetic Cad/Cam Restorative Materials. J Dent Fac Atatürk Uni 2018;28:365-70.

29. Pecho OE, Ghinea R, Ionescu AM, de la Cruz Cardona J, Paravina RD, del Mar Pérez M. Color and translucency of zirconia ceramics, human dentine and bovine dentine. J Dent 2012;40:34-40.

30. Yu B, Ahn JS, Lee YK. Measurement of translucency of tooth enamel and dentin. Acta Odontol Scand 2009;67:57-64.

31. Sannino G, Germano F, Arcuri L, Bigelli E, Arcuri

C, Barlattani A. Cerec CAD/CAM chairside system. Oral Implantol 2014;7:57-70.

32. Nakajima M, Arimoto A, Prasansuttiporn $T$, Thanatvarakorn O, Foxton RM, Tagami J. Light transmission characteristics of dentine and resin composites with different thickness. J Dent 2012;40:77-82.

33. Lim HN, Yu B, Lee YK. Spectroradiometric and spectrophotometric translucency of ceramic materials. J Prosthet Dent 2010;104:239-246.
34. Ahn JS, Lee YK. Difference in the translucency of all-ceramics by the illuminant. Dent Mater 2008;24:1539-1544.

35. Spink LS, Rungruanganut $P$, Megremis S, Kelly JR. Comparison of an absolute and surrogate measure of relative translucency in dental ceramics. Dent Mater 2013;29:702-707.

36. Erdelt K, Engler MLPD, Beuer F, Güth JF, Liebermann A, Schweiger J. Computable translucency as a function of thickness in a multi-layered zirconia. $\mathrm{J}$ Prosthet Dent 2018.

37. Walczak K, Meißner H, Range U, Sakkas A, Boening K, Wieckiewicz M, Konstantinidis I. Translucency of Zirconia Ceramics before and after Artificial Aging. J Prosthodont 2018.

38. Li Q, Yu H, Wang YN. Spectrophotometric evaluation of the optical influence of core build-up composites on all-ceramic materials. Dent Mater 2009;25:158-165.

39. Bayindir F, Kuo S, Johnston WM, Wee AG. Coverage error of three conceptually different shade guide systems to vital unrestored dentition. J Prosthet Dent 2007;98:175-185. 